\title{
Persepsi Guru Bidang Studi Ilmu Pengetahuan Alam Terhadap Pelaksanaan Pendekatan Saintifik Dalam Kurikulum 2013 Tingkat Sekolah Menengah Pertama Di Kecamatan Lengayang Kabupaten Pesisir Selatan
}

\section{Perception Of Natural Sciences Teachers In Implementation Of Scientific Learning In Curriculum 2013 In Junior High School In Lengayang District Pesisir Selatan}

\author{
Destaria Sudirman $^{1 *}$ dan Ennike Gusti Rahmi ${ }^{2}$ \\ ${ }^{12}$ Program Studi Pendidikan Biologi, STKIP Ahlussunnah Bukittinggi \\ *Koresponden: rhiasudirman@gmail.com
}

\begin{abstract}
Abstrak
Indonesia selalu mengalami perubahan kurikulum yang salah satunya yaitu kurikulum 2013. Perubahan kurikulum ini dilakukan pemerintah dengan tujuan perbaikan sistem pendidikan di Indonesia, dimana dalam kurikulum 2013 ini muncul berbagai pendapat atau tanggapan serta terjadi pro dan kotra dari berbagai pihak. Tujuan penelitian ini untuk mengkaji Persepsi dari setiap guru bidang studi Ilmu Pengatahuan Alam Sekolah Menengah Pertama di Kecamatan Lengayang Kabupaten Pesisir Selatan terhadap pelaksanaan Pendekatan Saintifik dalam kurikulum 2013. Jenis penelitian ini adalah deskriptif kualitatif. Populasi penelitian ini semua guru bidang studi Ilmu Pengatahuan Alam Sekolah Menengah Pertama di Kecamatan Lengayang dan yang menjadi sampel adalah guru bidang studi Ilmu Pengatahuan Alam yang sudah melaksanakan kurikulum 2013. Dalam pengumpulan data digunakan teknik observasi, wawancara, dan angket. Selanjutnya dianalisis menggunakan rumus persentase. Hasil penelitian ini menunjukkan bahwa persepsi guru bidang studi Ilmu Pengatahuan Alam Sekolah Menengah Pertama tentang pelaksanaan pembelajaran pendekatan saintifik dalam kurikulum 2013 tergolong cukup baik untuk penerapannya, namun masih terdapat kekurangan yaitu minimnya pelatihan yang diselenggarakan serta kurangnya sarana prasaran penunjang seperti alat-alat laboratorium yang kurang memadai.
\end{abstract}

Kata Kunci: Persepsi, Kurikulum 2013, Pendekatan Saintifik

\begin{abstract}
Indonesia always experience curriculum change which one of them is curriculum 2013. This curriculum change is done by the government with the aim of improving the education system in Indonesia, it caused by 2013 curriculum got many critics not only agree but also disagree from various particular. The aim of this research was to analyze perception of natural science teachers in junior high school in Lengayang District Pesisir Selatan in implementation scientific learning in 2013 curriculum. This research was qualitative with descriptive design the population was all of natural science teacher of junior high school in Lengayang District. Sample of this research was natural science teacher who had implemented the 2013 curriculum technique of collecting data was observation, interview, and questioner. Further analyzed using percentage formula. The results of this study indicate that teachers' perceptions of the Science of Natural Sciences of Junior High School about the implementation of learning scientific approach in the 2013 curriculum is quite good for its application, but there are still shortcomings that lack of training and lack of supporting facilities such as laboratory equipment less adequate.
\end{abstract}

Keywords: Perception, Curriculum 2013, Scientific Approach 


\section{PENDAHULUAN}

Pendidikan merupakan hal yang utama dalam pengembangan manusia Indonesia seutuhnya.Perkembangan pendidikan di Indonesia harus berjalan seperti bagaimana menciptakan perubahan yang lebih baik sesuai dengan perkembangan zaman.Maka dari itu, pendidikan diselenggarakan secara resmi maupun tidak dengan resmi. Contoh pendidikan resmi berlangsung di sekolah, dari tingkat yang terendah sampai tingkat yang tertinggi yaitu: taman kanak-kanak (TK), sekolah dasar (SD), sekolah menengah pertama (SMP), sekolah menengah atas (SMA), hingga di perguruan tinggi. Sedangkan pendidikan tidak resmi yaitu pendidikan yang dilaksanakan di keluarga dan lingkungan masyarakat.

Pendidikan ini dipercayai mampu menanamkan kemampuan yang baru bagi semua orang untuk mempelajari pengetahuan dan keterampilan baru, sehingga dapat diperoleh manusia yang lebih unggul. Salah satu upaya perkembangan itu ditempuh dengan menerapkan perubahan kurikulum baru yaitu kurikulum 2013 yang disusun dengan dilandasi pemikiran tantangan masa depan, yaitu tantangan abad ke-21 dilandasi dengan abad ilmu pengetahuan dan kompetensi masa depan (Kurinasih dan Sani, 2014). Perubahan kurikulum ini dilakukan pemerintah dengan tujuan perbaikan sistem pendidikan di Indonesia. Pengembangan kurikulum pada hakikatnya adalah proses penyusunan rencana tentang isi dan bahan pelajaran yang harus dipelajari serta bagaimana cara mempelajarinya (Sanjaya, 2008).

Dari hasil observasi yang dilakukan peneliti bulan oktober 2017 di beberapa SMPN Kecamatan Lengayang Kabupaten Pesisir Selatan didapatkan informasi bahwa kelas VII dan kelas VIII pada proses pembelajarannya sudah menggunakan kurikulum 2013, namun untuk pembelajaran di kelas IX tetap difokuskan pada kurikulum lama yaitu kurikulum tingkat satuan pendidikan (KTSP). Pelaksanaan kurikulum 2013 di kelas VII dan VIII telah dilaksanakan hingga tiga semester.Selama kurang lebih satu setengah tahun pelaksanaan kurikulum pada kelas VII dan VIII ternyata tidak sedikit guru yang merasa sulit untuk bisa menerapkan pembelajaran di kelas dengan kurikulum 2013 tersebut. Kesulitan itu dipandang dari aspek teknik selama proses pembelajaran diantaranya penerapan pendekatan saintifik yaitu pendekatan yang digunakan dalam pembelajaran dilakukan melalui proses ilmiah (Fadlillah, 2014). Dalam proses pembelajaran siswa dapat menemukan jawaban dari permasalahan pembelajaran. Namun pada kenyataannya guru belum bisa mengarahkan siswa dalam pelaksanaan pendekatan saintifik secara optimal. Selain itu kelas yang kurang 
terkendali dapat mengakibatkan tidak tercapainya tujuan pembelajaran yang dilaksanakan oleh guru.

Kegiatan evaluasi dan teknis penilaian dan pelaksanaan kurikulum 2013 merupakan aspek lain yang dipandang sulit untuk diaplikasikan oleh guru dalam pembelajaran di kelas. Karena proses penilaian pembelajaran menggunakan pendekatan penilaian otentik atau authentic assessment (Abdullah, 2014). Guru diharuskan merekapitulasi semua aspek penilaian baik secara kognitif, keterampilan, dan sikap (etika siswa) selama proses pembelajaran berlangsung, dengan adanya format penilaian yang begitu banyak membuat guru merasa kesulitan dalam mengoptimalkan waktu pada penerapan saintifik dalam kurikulum 2013. Hal ini juga merupakan tahap awal penyesuaian guru dari pelaksanaan perubahan kurikulum lama dengan penerapan kurikulum yang baru.

Dari perkembangan kurikulum 2013 ini diharapkan mampu mencapai penerapannya dengan hasil yang diinginkan. Namun dalam pelaksanaan kurikulum ini juga banyak mengundang pro dan kontra yang menimbulkan persepsi yang berbeda diantara guru.Persepsi tersebut ada yang positif dan ada yang negatif. Dalam hal pengertian persepsi ini sendiri adalah bagaimana pandangan guru itu sendiri terhadap pelaksaaan kurikulum 2013. Berdasarkan paparan di atas maka tujuan penelitian ini untuk mengetahui Persepsi Guru Bidang Studi Ilmu Pengetahuan Alam Terhadap Pelaksanaan Pendekatan Saintifik Dalam Kurikulum 2013 Tingkat Sekolah Menengah Pertama Di Kecamatan Lengayang Kabupaten Pesisir Selatan.

\section{METODE PENELITIAN}

Penelitian ini termasuk penelitian deskriptif yang bersifat kualitatif. Dimana, penelitian kualitatif adalah prosedur penelitian yang menghasilkan data deskriptif berupa kata-kata tertulis atau lisan dari orang-orang dan perilaku yang dapat diamati (Margono, 2010). Data yang diperoleh dari lapangan akan dideskripsikan melalui kata-kata oleh peneliti. Dapat pula dikatakan bahwa penelitian deskriptif kualitatif dimaksudkan untuk mengangkat fakta, keadaan, variabel dan fenomena yang terjadi (ketika penelitian sedang berlangsung) dan menyajikan apa adanya. Sehingga dalam penelitian ini tidak perlu menguji hipotesis dan membuat ramalan hasil.

Subjek dalam penelitian ini adalah seluruh guru Sekolah Menengah Pertama Bidang Studi Ilmu Pengetahuan Alam yang ada di Kecamatan Lengayang Kabupaten Pesisir Selatan, 
dan sampelnya adalah guru Sekolah Menengah Pertama bidang studi Ilmu Pengatahuan Alam di Kecamatan Lengayang Kabupaten Pesisir Selatan yang sudah melaksanakan kurikulum 2013. Sampel dalam penelitian ini penulis gunakan sebagai sumber data yang dianggap telah melaksanakan kurikulum 2013.Untuk menentukan sampel, pada penelitian ini digunakan tehnik sampling jenuh atau total sampling yaitu tehnik penentuan sampel bila semua anggota populasi digunakan sebagai sampel (Sugiyono, 2014). Teknik pengumpulan data yang digunakan dalam penelitian ini adalah observasi, wawancara, quisoner (angket) dan dokumentasi. Kisi-kisi angket merujuk pada Kosasih (2014), sebagai berikut.

Tabel 1. Kisi-kisi angket tentang persepsi guru bidang studi IPASMP diKecamatan Lengayang Kabupaten Pesisir Selatan terhadap pelaksanaan pendekatan saintifik dalam kurikulum 2013.

\begin{tabular}{clcc}
\hline No & \multicolumn{1}{c}{ Indikator } & Butir soal & Jumlah \\
\hline 1 & $\begin{array}{l}\text { Pemahaman pembelajaran pendekatan sanitifik } \\
\text { dalam kurikulum 2013 }\end{array}$ & $1,2,3,4,5$ & 5 \\
2 & $\begin{array}{l}\text { Kesiapan pembelajaran pendekatan sanitifik } \\
\text { dalam kurikulum 2013 }\end{array}$ & $6,7,8,9,10,11$ & 6 \\
3 & $\begin{array}{l}\text { Penerapan atau pelaksanaan pembelajaran } \\
\text { pendekatan sanitifik dalam kurikulum 2013 }\end{array}$ & $12,13,14,15,16,17$ & 6 \\
4 & $\begin{array}{l}\text { Kesulitan pembelajaran pendekatan sanitifik } \\
\text { dalam kurikulum 2013 }\end{array}$ & $18,19,20,21,22$ & 5 \\
\hline
\end{tabular}

Sebelum angket ini digunakan, maka terlebih dahulu divalidasi oleh 2 orang dosen yaitu Citra Ayu, M.Pd dan Rico Aprisa, S.Pd., M.Si. Selanjutnya data yang diperoleh dari instrument penelitian dianalisis dan diolah dengan menggunakan teknik persentase (Sudijono, 2008).

\section{HASIL DAN PEMBAHASAN}

Berdasarkan hasil wawancara dengan Ibu Nelfianti, M.Pd Kasi Kurikulum dan Penilaian SMP Dinas Pendidikan dan Kabupaten Pesisir Selatan dan observasi lapangan didapatkan informasi bahwa kurikulum 2013 diterapkan pada semester pertama tahun ajaran 2016. Tetapi tidak semua sekolah menerapkan kurikulum ini. Hanya sekolah yang ditunjuk pemerintahan saja yang dianggap mampu menjadi contoh untuk sekolah lainnya. Diantara sekolah yang menerapkan kurikulum 2013 dapat dilihat pada Tabel 2. 
Tabel 2. Data Sekolah yang telah menerapkan Kurikulum 2013

\begin{tabular}{ccc}
\hline No & Nama Sekolah & Kurikulum \\
\hline 1 & SMPN 1 Lengayang & Kurikulum 13 \\
2 & SMPN 2 Lengayang & Kurikulum 13 \\
3 & SMPN 3 Lengayang & Kurikulum 13 \\
4 & SMPN 4 Lengayang & Kurikulum 13 \\
5 & SMPN 5 Lengayang & KTSP \\
6 & SMPN 6 Lengayang & KTSP \\
\hline
\end{tabular}

Berdasarkan hasil penelitian yang didapat dari 20 soal instrumen dengan 13 orang responden dari 4 sekolah yang tersebar di Kecamatan Lengayang Kabupaten Pesisir Selatan dilakukan analisis dan pengolahan data dengan menggunakan teknik persentase dilihat dari jawaban angket responden yaitu guru-guru IPA SMP mengenai "Persepsi Guru Bidang Studi Ilmu Pengetahuan Alam Terhadap Pelaksanaan Pendekatan Saintifik Dalam Kurikulum 2013 Tingkat Sekolah Menengah Pertama Di Kecamatan Lengayang Kabupaten Pesisir Selatan” dapat dilihat pada Tabel 3.

Tabel 3. Pengelompokkan Data Hasil Penelitian Berdasarkan Indikator

\begin{tabular}{|c|c|c|c|c|c|c|}
\hline No & $\begin{array}{c}\text { Item } \\
\text { Instrumen }\end{array}$ & Indikator & $\begin{array}{l}\text { Skor Item } \\
\text { (R) }\end{array}$ & $\begin{array}{c}\text { Skor } \\
\text { Maksimal } \\
(\mathbf{N})\end{array}$ & $\begin{array}{c}\text { Persentase } \\
\%\end{array}$ & Kategori \\
\hline 1 & $1-4$ & $\begin{array}{l}\text { Pemahaman } \\
\text { Pembelajaran } \\
\text { Pendekatan Saintifik } \\
\text { dalam Kurikulum } \\
2013\end{array}$ & 158 & 208 & $75,96 \%$ & Cukup \\
\hline 2 & $5-10$ & $\begin{array}{l}\text { Kesiapan } \\
\text { pembelajaran } \\
\text { pendekatan sanitifik } \\
\text { dalam kurikulum } 2013\end{array}$ & 199 & 312 & $63,78 \%$ & Cukup \\
\hline 3 & $11-16$ & $\begin{array}{l}\text { Penerapan atau } \\
\text { pelaksanaan } \\
\text { pembelajaran } \\
\text { pendekatan sanitifik } \\
\text { dalam kurikulum } 2013\end{array}$ & 219 & 312 & $70,19 \%$ & Cukup \\
\hline 4 & $17-20$ & $\begin{array}{l}\text { Kesulitan } \\
\text { pembelajaran } \\
\text { pendekatan sanitifik } \\
\text { dalam kurikulum } 2013\end{array}$ & 155 & 208 & $74,52 \%$ & Cukup \\
\hline \multicolumn{3}{|c|}{$\begin{array}{l}\text { Persepsi Guru Bidang Studi Ilmu } \\
\text { Pengetahuan Alam Sekolah Menengah } \\
\text { Pertama di Kecamatan Lengayang } \\
\text { Kabupaten Pesisir Selatan terhadap } \\
\text { Pelaksanaan Pendekatan Saintifik dalam } \\
\text { Kurikulum } 2013\end{array}$} & 731 & 1.040 & $70,29 \%$ & Cukup \\
\hline
\end{tabular}


Destaria Sudirman dan Ennike Gusti Rahmi: Persepsi Guru Bidang Studi Ilmu Pengetahuan Alam...

Berdasarkan hasil wawancara peneliti dengan Ibu Maiyusri Eka Putri, S.Pd Guru IPA SMPN 1 Lengayang bahwa kurikulum 2013 ini baik diterapkan pada proses pembelajaran, karena langkah-langkah pembelajaran yang menuntun siswa aktif karena pendekatan saintifik yang diterapkan pada kurikulum 2013 dapat membuat siswa lebih aktif, kreatif dan inovatif dalam mencari informasi, dan pemecahan masalah. Pembelajaran juga lebih terarah karena adanya langkah-langkah dalam pembelajaran pendekatan saintifik karena berkaitan erat dengan metode saintifik. Abdullah (2014) mengatakan metode saintifik melibatkan kegiatan pengamatan atau observasi, mengumpulkan data, memaparkan data yang diperoleh melalui pengamatan atau percobaan yang dapat diganti dengan kegiatan memperoleh informasi dari berbagai sumber. Metode ilmiah merujuk pada teknik-teknik investigasi atas fenomena atau gejala, memperoleh pengetahuan baru, atau mengoreksi dan memadukan pengetahuan sebelumnya. Untuk dapat disebut ilmiah, metode pencarian (method of inquiry) harus berbasis pada bukti-bukti dari objek yang dapat diobservasi, empiris, dan terukur dengan prinsipprinsip penalaran yang spesifik (Agus, et al., 2016). Hanya saja dalam pelaksanaannya masih cukup rumit karena siswa belum memahami betul langkah-langkah pembelajaran saintifik karna terbiasanya menggunakan pembelajaran konvensional. Menurut Sanjaya (2010) pembelajaran konvensional siswa ditempatkan sebagai objek belajar yang berperan sebagai penerima informasi secara pasif. Selain itu sarana prasarana penunjang pada sekolah belum memadai seperti kurangnya buku pembelajaran yang tersedia disekolah, peralatan laboratorium yang kurang lengkap.

Informasi yang dihimpun dari Ibu Yusmaniar, S.Pd guru IPA SMPN 2 Lengayang mengatakan bahwa guru masih kesulitan mengarahkan siswa menggunakan pembelajaran pendekatan saintifik karena motivasi belajar siswa masih kurang. Motivasi sangat mempengaruhi karena berkaitan dengan kondisi psikologis yang mendorong siswa untuk belajar secara sungguh-sungguh, yang pada gilirannya akan terbentuk cara belajar siswa yang sistematis, penuh konsentrasi dan dapat menyeleksi kegiatan-kegiatannya (Sardiman, 2005). Pola pembelajaran pada kurikulum 2013 menekankan kepada pembelajaran siswa aktif. Siswa dapat mencari dan menemukan sendiri melalui pendekatan saintifik, baik secara individu maupun kelompok. Dengan demikian siswa dapat memperoleh ilmu dari siapa saja dan darimana saja yang dapat dihubungi termasuk diperoleh melalui internet (Fitria, et al., 2018). Pendekatan saintifik dimaksudkan untuk memberikan pemahaman kepada peserta didik dalam mengenal, memahami berbagai materi menggunakan pendekatan ilmiah, bahwa informasi 
bisa berasal dari mana saja, kapan saja, tidak bergantung pada informasi searah dari guru.Kondisi pembelajaran yang diharapkan tercipta diarahkan untuk mendorong peserta didik dalam mencari tahu dari berbagai sumber melalui observasi, dan bukan hanya diberi tahu (Sufairoh, 2016).

Data lain dari wawancara Ibu Ernitayati, S.Pd mengatakan bahwa guru IPA SMPN 3 Lengayang mengakui kurikulum 2013 ini sangat baik untuk diterapkan. Hanya saja saat ini pemerintah masih kurang dalam persiapan penerapannya. Dibuktikan dengan adanya guru yang hanya sekali mengikuti pelatihan bahkan ada yang belum pernah mengikutinya. Pelatihan kurikulum belum maksimal diikuti hanya beberapa pertemuan saja dari Dinas Pendidikan. Sementara sekolah sendiri secara pribadi tidak dapat menghadirkan tim kurikulum untuk pelatihan pembelajaran guru-guru di sekolah dengan alasan keterbatasan biaya menghadirkan narasumber kurikulum 2013. Sehingga ada guru yang mengatakan belum begitu mengerti tentang sistem yang ada dalam pembelajaran saintifik apalagi dengan penilaian yang harus merekapitulasi begitu banyak sangatlah membutuhkan waktu panjang. Hal ini sesuai dengan apa yang dinyatakan Abdullah (2014) bahwa dalam hal penilaian pembelajaran saintifik mencakupranah sikap, pengetahuan, dan keterampilan. Harapan guru, Pemerintah hendaknya memberikan pelatihan yang lebih kepada guru-guru secara maksimal tentang perubahan sistem pembelajaran yang baru sebelum kurikulum 2013 diterapkan.

\section{KESIMPULAN}

Hasil penelitian menunjukkan bahwa persepsi guru tentang pembelajaran pendekatan saintifik dalam kurikulum 2013 tergolong cukup. Untuk penerapannya saat ini ada sebagian guru yang masih belum terlalu paham dengan langkah-langkah pembelajaran saintifik dalam kurikulum 2013, hal ini disebabkan penerapan kurikulum 2013 yang baru berjalan 1 (satu) - 5 (lima) semester. Selain itu kurangnya pelatihan yang diselenggarakan pemerintah, sehingga guru-guru masih banyak terkendala dalam proses pelaksanaan pembelajaran berdasarkan pendekatan saintifik dan sistem penilaian yang begitu otentik.

\section{UCAPAN TERIMA KASIH}

Terima kasih disampaikan kepada Direktorat Riset dan Pengabdian Masyarakat Direktorat Jenderal Penguatan Riset dan Pengembangan Kementerian Riset, Teknologi dan 
Pendidikan Tinggi yang telah mendanai penelitian ini Sesuai dengan Kontrak Penelitian NOMOR: 005/Kontrak/LPPM/STKIP-Ahls/Q-2018 serta seluruh pihak yang telah membantu kelancaran penelitian ini.

\section{REFERENSI}

Abdullah, R.S. 2014. Pembelajaran Saintifik Untuk Implementasi Kurikulum 2013. PT. Bumi Aksara, Jakarta.

Agus, M.K.B., Waluyo, L., Mokhtar, A. 2016. Implementasi Pendekatan Saintifik dalam Pembelajaran di Pendidikan Dasar di Malang. Proceeding Biology Education Conference. Universitas Muhammadiyah Malang. Vol 13 (1):46-51.

Fadlillah. 2014. Implementasi Kurikulum 2013 Dalam Pembelajaran SD/MI, SMP/MTs, dan SMA/MA. AR-Ruzz Media, Yogyakarta.

Fitria, M.A., Sudirman, D., Arimadona, S. 2016. Persepsi Siswa MIPA Kelas X Terhadap Pelaksanaan Proses Pembelajaran Biologi Berdasarkan Kurikulum 2013 SMAN 2 Bukittinggi. SIMBIOSA, Vol. 6 (2):67-73.

Kosasih. 2014. Strategi Belajar Dan Pembelajaran Implementasi Kurikulum 2013. Yrama Widya, Bandung.

Kurinasih dan Sani. 2014. Sukses Mengimplementasikan Kurikulum 2013. Kata Pena, Surabaya.

Margono. 2010. Metodologi Penelitian Pendidikan. PT Asdi Mahasatya, Jakarta.

Sanjaya, W. 2008. Kurikulum dan Pembelajaran. Kencana, Jakarta.

2010. Strategi Pembelajaran Berorientasi Standar Proses Pendidikan. Prenada Media Group, Jakarta.

Sardiman. 2005. Interaksi dan Motivasi Belajar Mengajar. Raja Grafindo Persada, Jakarta.

Sudijono. 2008. Pengantar Statistik Pendidikan. PT. Raja Grafindo Persada, Jakarta.

Sufairoh. 2016. Pendekatan Saintifik \& Model Pembelajaran K-13. Jurnal Pendidikan Profesional, Volume 5 (3): 116-125

Sugiyono. 2014. Metode Penelitian Kombinasi. Alfabeta, Bandung. 